\title{
WEED INFESTATION OF A WINTER WHEAT CANOPY UNDER THE CONDITIONS OF APPLICATION OF DIFFERENT HERBICIDE DOSES AND FOLIAR FERTILIZATION
}

\author{
Piotr Kraska $^{1}$, Sylwia Okoń ${ }^{2}$, Edward Pałys ${ }^{1}$ \\ ${ }^{1}$ Department of Agricultural Ecology, University of Life Science in Lublin, Akademicka 13, 20-950 Lublin, Poland \\ ${ }^{2}$ Institute of Plant Genetics, Breeding and Biotechnology, University of Life Science in Lublin, Akademicka 15 \\ 20-950 Lublin, Poland \\ e-mail: piotr.kraska@up.lublin.pl
}

Received: 4.06.2009

\section{Abstract}

The present study was carried out in the years 20062008 in the Bezek Experimental Farm (University of Life Sciences, Lublin). A two-factor field experiment was set up according to a randomized block design, in three replications. The experimental field was situated on medium heavy mixed rendzina developed from chalk rock with medium dusty loam granulometric composition. The soil was characterised by neutral $\mathrm{pH}$, a very high content of $\mathrm{P}$ (342.1) and $\mathrm{K}$ (278.9) along with a very low level of magnesium (16.0 mg $\times \mathrm{kg}^{-1}$ of soil) and organic carbon (over $3.5 \%$ ). The aim of this research was to compare the effect of three herbicide doses and two foliar fertilizers applied in a winter wheat canopy on weed infestation. The herbicides

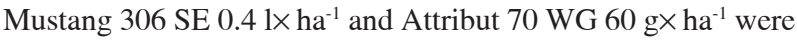
applied at full recommended doses as well as at doses reduced to $75 \%$ and $50 \%$. Foliar fertilizers Insol $3\left(11 \times \mathrm{ha}^{-1}\right)$ and FoliCare $\left(20 \mathrm{~kg} \times \mathrm{ha}^{-1}\right)$ were applied at full recommended doses twice in the growing season $\mathrm{BBCH}^{*}$ development stage $23-25^{*}$ and $33-35^{*}$ ). The control was not treated with the herbicides and foliar fertilizers. The weed infestation level was determined by means of the quantitative gravimetric method at two dates: the first one 6 weeks after herbicide application and the second one - before harvest. The number of weed individuals was counted; species composition and air-dry biomass of aboveground parts were estimated from randomly selected areas of $1 \mathrm{~m} \times 0.25 \mathrm{~m}$ at four sites on each plot. Galium aparine and Apera spica-venti plants were sampled for molecular analysis 6 weeks after herbicide application (the treatments with the full herbicide dose, a $50 \%$ dose and the control without herbicides). The density of weeds and weed air-dry weight were statistically analysed by means of variance analysis, and the mean values were estimated with Tukey's confidence intervals $(\mathrm{p}=0.05)$.

It was found that the number of weeds and air-dry weight of weeds in the control treatment were significantly higher in comparison with the herbicide treated plots. The application of different herbicide doses did not differentiate significantly the weed infestation level in the winter wheat canopy. Galium aparine, Papaver rhoeas, Viola arvensis and Apera spica-venti were dominant weed species in the winter wheat canopy. Foliar application of fertilizers did not influence the weed infestation level in the crop canopy. Molecular analysis showed that herbicide application did not affect genetic variation in the populations of Galium aparine and Apera spica-venti.

Key words: doses of herbicides, foliar application of fertilizers, winter wheat, weed infestation, DNA analysis RAPD, genetic variation

\section{INTRODUCTION}

Reduced herbicide doses used in cereals decrease weed control costs and reduce environmental contamination risks (Domaradzki and Rola 1999, B lackshaw et al. 2006). Domaradzki and Rola (2000, 2004), Domaradzki (2006b), $\mathrm{Kraska}(2007 \mathrm{ab})$ as well as Kraska and Pałys (2008) indicate the possibility of reducing herbicide rates by as much as $50 \%$ without the risk of decreasing grain yields, at the same time maintaining the required weed-killing effectiveness. In addition to the destruction of weeds, herbicide treatments weaken their condition and cause flowering and fruiting disorders (Rola, 1991).

Cleavers belongs to species which are very often found in a winter wheat canopy. This species exhibits a very high tolerance to habitat conditions ( $\mathrm{No}$ wicki, 1977). At the same time, it is very prolific. Malicki and Kwiecińska (1999) found that one G. aparine plant was capable of producing even 1820 diaspores. Adamczewski and Praczyk (1999), Rola (2002) as well as Kraska (2006, 2007a) indicate the dominant role of cleavers in weed infestation of winter wheat. In practice, G. aparine is 
controlled primarily by the use of herbicides (W e i d e , 1993). Adamczewski and Praczyk (1999) claim that, among monocotyledonous weeds Apera spica-venti poses the greatest threat to winter cereals. Kapeluszny and Haliniarz (2007) point out risks resulting from the possibility of this species becoming resistant to certain active substances of commonly used herbicides.

The aim of the present study was to compare the effectiveness of different herbicide doses and foliar fertilization in the reduction of weed infestation of a winter wheat canopy. At the same time, an attempt was made to verify whether the herbicide rate might affect variation in genetic similarity (DNA changes) of species most frequently found in a winter wheat crop - Galium aparine and Apera spica-venti.

\section{MATERIALS AND METHODS}

The experiment was carried out in the years 2003-2005 in the Bezek Experimental Farm, belonging to the University of Life Sciences in Lublin. The experimental field was located on medium heavy mixed rendzina soil, developed from chalk rock with the granulometric composition of medium silty loam. This soil had a neutral $\mathrm{pH}$, very high content of $\mathrm{P}$ 342.1 and $\mathrm{K}-278.9$ as well as very low magnesium content -16.0 (values expressed in $\mathrm{mg} \times \mathrm{kg}^{-1}$ of soil), very high organic carbon content - over $3.5 \%$, and it was classified as IIIb soil quality class and defective wheat complex.

The experiment was conducted in a randomized block design in three replications. The action of three herbicide doses and two foliar fertilizers was compared in a crop of winter wheat cv. Turnia. The herbicides were applied at full recommended doses, at doses reduced to $75 \%$ and reduced by half. The foliar fertilizers were applied at recommended doses. The plots in which neither herbicides nor foliar fertilizers were applied were the control. Tillage was done following generally accepted agricultural practice recommendations. Seeds dressed with the seed dressing agent Panoctine 300 LS (a biologically active substance - guazatine in the form of acetate) were sown at an amount of 500 grains per $\mathrm{m}^{2}$. Mineral fertilizer doses were as follows: $\mathrm{N}-120 \mathrm{~kg} \times \mathrm{ha}^{-1} ; \mathrm{P}_{2} \mathrm{O}_{5}-100 \mathrm{~kg} \times \mathrm{ha}^{-1} ; \mathrm{K}_{2} \mathrm{O}$ $-120 \mathrm{~kg} \times \mathrm{ha}^{-1}$. Phosphorus and potassium fertilizers as well as $30 \mathrm{~kg} \mathrm{~N} \times \mathrm{ha}^{-1}$ were applied pre-sowing. The remaining part of the nitrogen dose was applied before the start of the growing season at the rate of $60 \mathrm{~kg} \times \mathrm{ha}$ ${ }^{1}$ and $30 \mathrm{~kg} \times \mathrm{ha}^{-1}$ at the shooting stage. In addition, the following plant protection agents were used: the herbicides Mustang 306 SE 0.4 l $\times$ ha $^{-1}$ - basic rate $-(\mathrm{BBCH}$ development stage 23-25*), as well as Attribut $70 \mathrm{WG}$ $60 \mathrm{~g} \times \mathrm{ha}^{-1}-$ basic rate $-\left(23-25^{*}\right)$, Alert 375 SC 1.0
$1 \times$ ha $^{-1}-(26-29 *)$, Tango 500 SC $0.81 \times$ ha $^{-1}-\left(51-56^{*}\right)$, Terpal C 460 SL 2.5 l× ha-1 - (32-39*).

The herbicides Mustang 306 SE (containing two active substances: florasulam - a compound

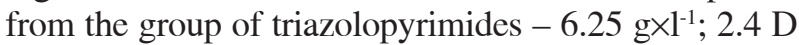
EHE - a compound from the group of phenoxyacids

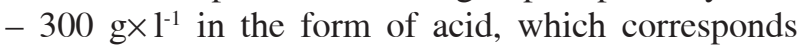
to a content of $452 \mathrm{~g} \times \mathrm{l}^{-1}$ in the form of 2-ethylhexyl ester) as well as Attribut $70 \mathrm{WG}$ (containing $70 \%$ of propoxycarbazone sodium - a compound from the group of sulfonyl-aminocarbonyl triazolinones) were applied jointly. Foliar fertilization was applied twice during the growing period (BBCH stage 23-25 and 33-35) using the following foliar fertilizers: Insol 3 (N-11.5\%; $\mathrm{Mg}-2.84 \% ; \quad \mathrm{B}-0.28 \% ; \quad \mathrm{Cu}-0.56 \%$; Fe-1.20\%; Mn-1.68\%; Mo-0.01\%; Zn-1.12\%) at a dose of $1 \mathrm{l} \times \mathrm{ha}^{-1}$ and FoliCare (N-18.0\%; P-18.1\%; K-18.0\%; Mg-1.5\%; S-7.2\%; B-0.02\%; Cu- $0.10 \%$; Fe-0.20\%; Mn-0.10; Mo-0.01\%; Zn-0.02\%) at a dose of $20 \mathrm{~kg} \times \mathrm{ha}^{-1}$. Weed infestation of the crop canopy was determined twice using the quantitative gravimetric method: the first time about 6 weeks after herbicide treatment (BBCH development stage 41-45), the second time before winter wheat harvesting (BBCH stage 89-92). The number of weeds, species composition and air-dry weight of above-ground parts of weeds were determined from the sampling areas surrounded by a frame of $1 \mathrm{~m} \times 0.25 \mathrm{~m}$ in four randomly selected sites of each plot, in accordance with the recommendations given in the paper of $\mathrm{Badowski}$ et al. (2001). The effectiveness of the action of the herbicides was evaluated by comparing weed infestation of the herbicide-treated plots with the control plots without herbicide application. The obtained results were statistically analysed by means of variance analysis. The mean values were compared by means of the least significant differences using Tukey's test.

In 2008, after six weeks from herbicide application, material for DNA analysis was sampled from the most frequently found species of the dicotyledonous and monocotyledonous classes - Galium aparine and Apera spica-venti. Samples were collected from the plots in which a full herbicide dose was applied, a dose reduced by half as well as from the control treatment. 8 plant samples were collected from each plot. DNA from the studied species was isolated from leaves using the CTAB method (D o yle and Doyle, 1987).

The PCR response was carried out using the modified method of W illi a m s et al. (1990). The 15 $\mu$ l-volume reaction mixture comprised: $1 \times$ PCR buffer (10 mM Tris pH 8.8, $50 \mathrm{mM} \mathrm{KCl,} \mathrm{0.08 \%} \mathrm{Nonidet} \mathrm{P40)}$ (Fermentas, Lithuania), $160 \mu \mathrm{M}$ of each dNTP, $5.3 \mathrm{pM}$ of the primer, $1 \mathrm{mM} \mathrm{MgCl}, 60 \mathrm{ng}$ of genomic DNA, 0.4 U Taq DNA Polymerase (Fermentas, Lithuania). Amplification reactions were performed using a $\mathrm{T} 1$ 
Thermocycler (Biometria) for two DNA samples from each genotype, at the same time performing the control reaction without DNA template. The following thermal profile was applied: initial denaturation for $3 \mathrm{~min}$. at $94^{\circ} \mathrm{C}, 44$ cycles: $94^{\circ} \mathrm{C}-45 \mathrm{~s}, 37^{\circ} \mathrm{C}-45 \mathrm{~s}, 72^{\circ} \mathrm{C}-45 \mathrm{~s}$, with final incubation for $7 \mathrm{~min}$. at $72^{\circ} \mathrm{C}$. The reaction products were electrophoresed on a $1.5 \%$ agarose gel containing ethidium bromide. The gels were visualised on a transiluminator and photographed using the Poly Doc gel documentation system.

In polymorphism analysis, the presence or absence of a band was treated as a single trait and it was assigned the value of 1 or 0 . The pairwise similarity index (SI) for all the investigated forms was estimated according to Dice's formula [ $\mathrm{N} \mathrm{e} \mathrm{i} \mathrm{and} \mathrm{Li} \mathrm{,} \mathrm{1979].} \mathrm{Based} \mathrm{on} \mathrm{the}$ SI matrix, the UPGMA (unweighted pair group method with arithmetic average) analysis was performed using NTSYS-pc 2.10 q software (R o h $1 \mathrm{f}, 2001$ ).

\section{RESULTS}

The weed infestation level in the winter wheat canopy, measured by the number of dicotyledonous weeds, total number of weeds and their air-dry weight, was significantly lower in the herbicide-treated plots than in the control plots. Such a correlation was found at both dates of weed infestation estimation. However, the number of monocotyledonous weeds was not significantly differentiated by the herbicide doses applied, at both estimation dates. However, a tendency of the occurrence of a larger number of monocotyledonous taxa in the control treatments was observed (Tab. 1). Foliar fertilization did not have a significant effect on the weed infestation level in the winter wheat canopy (Tab. 2). At the same time, there was no interaction between the herbicide doses applied and foliar fertilization.

Table 1

Weed infestation of a winter wheat canopy per $1 \mathrm{~m}^{2}$ in dependent on doses of herbicides (means from the years 2006-2008).

\begin{tabular}{|c|c|c|c|c|c|}
\hline \multirow{3}{*}{ Number and dry weight of weeds } & \multicolumn{5}{|c|}{ Doses of herbicides } \\
\hline & $\mathrm{A}^{*}$ & B & $\mathrm{C}$ & $\mathrm{D}$ & \multirow{2}{*}{$\mathrm{LSD}_{0.05}$} \\
\hline & \multicolumn{4}{|c|}{$1^{\text {st }}$ date } & \\
\hline Number of dicotyledonous weeds & 115.3 & 43.3 & 43.9 & 58.9 & 28.8 \\
\hline Number of monocotyledonous weeds & 23.5 & 17.3 & 21.6 & 20.6 & $* * \mathrm{~ns}$ \\
\hline Total number of weeds & 138.8 & 60.6 & 65.5 & 79.5 & 30.9 \\
\hline \multirow[t]{2}{*}{ Air dry weight of weeds in $\mathrm{g} \times \mathrm{m}^{-2}$} & 157.5 & 22.2 & 24.3 & 38.3 & 25.6 \\
\hline & \multicolumn{4}{|c|}{$2^{\text {nd }}$ date } & \\
\hline Number of dicotyledonous weeds & 31.2 & 18.4 & 17.3 & 18.9 & 9.8 \\
\hline Number of monocotyledonous weeds & 24.0 & 16.9 & 22.9 & 21.2 & $* * \mathrm{~ns}$ \\
\hline Total number of weeds & 55.2 & 35.3 & 40.2 & 40.1 & 18.0 \\
\hline Air dry weight of weeds in $\mathrm{g} \times \mathrm{m}^{-2}$ & 296.7 & 54.9 & 68.0 & 67.6 & 55.8 \\
\hline
\end{tabular}

${ }^{\star} \mathrm{A}-$ control (without herbicides)

B - full doses of herbicides

C $-75 \%$ doses of herbicides

$\mathrm{D}-50 \%$ doses of herbicides

${ }^{* *}$ ns - not significant difference

Table 2

Weed infestation of a winter wheat canopy per $1 \mathrm{~m}^{2}$ in dependent on foliar fertilization application (means from the years 2006-2008).

\begin{tabular}{|c|c|c|c|c|}
\hline \multirow{3}{*}{ Number and dry weight of weeds } & \multicolumn{4}{|c|}{ Foliar fertilizers } \\
\hline & Control & Insol & FoliCare & \multirow{2}{*}{$\mathrm{LSD}_{0.05}$} \\
\hline & & $1^{\text {st }}$ date & & \\
\hline Number of dicotyledonous weeds & 66.9 & 65.4 & 63.6 & $*$ ns \\
\hline Number of monocotyledonous weeds & 16.8 & 23.1 & 22.4 & $* \mathrm{~ns}$ \\
\hline Total number of weeds & 83.7 & 88.5 & 86.0 & $* \mathrm{~ns}$ \\
\hline \multirow[t]{2}{*}{ Air dry weight of weeds in $\mathrm{g} \times \mathrm{m}^{-2}$} & 63.7 & 59.8 & 58.2 & $*$ ns \\
\hline & & $2^{\text {nd }}$ date & & \\
\hline Number of dicotyledonous weeds & 20.7 & 20.3 & 23.4 & $*$ ns \\
\hline Number of monocotyledonous weeds & 16.6 & 20.6 & 26.6 & $*_{\mathrm{ns}}$ \\
\hline Total number of weeds & 37.3 & 40.9 & 50.0 & $*$ ns \\
\hline Air dry weight of weeds in $\mathrm{g} \times \mathrm{m}^{-2}$ & 105.0 & 115.8 & 144.7 & $*_{\mathrm{ns}}$ \\
\hline
\end{tabular}

*ns - not significant difference 
Table 3

Species composition and number of weeds per $1 \mathrm{~m}^{2}$ of a winter wheat canopy at the first date of weed infestation estimation (BBCH development stage 41-45) in dependent on doses of herbicides (means from the years 2006-2008).

\begin{tabular}{|c|c|c|c|c|}
\hline \multirow{2}{*}{ Species } & \multicolumn{4}{|c|}{ Doses of herbicides } \\
\hline & $* \mathrm{~A}$ & $\mathrm{~B}$ & $\mathrm{C}$ & $\mathrm{D}$ \\
\hline \multicolumn{5}{|l|}{ Dicotyledonous } \\
\hline 1. Galium aparine $\mathrm{L}$. & 65.7 & 13.7 & 17.0 & 23.1 \\
\hline 2. Papaver rhoeas L. & 24.6 & 2.8 & 3.7 & 8.3 \\
\hline 3. Viola arvensis Murray & 9.7 & 20.7 & 17.1 & 19.1 \\
\hline 4. Camelina sativa (L.) Crantz & 6.1 & - & - & - \\
\hline 5. Stellaria media (L.) Vill. & 2.8 & 0.2 & 0.4 & 1.0 \\
\hline 6. Matricaria maritima subsp. inodora (L.) Dostál & 2.3 & 0.0 & 0.3 & 0.4 \\
\hline 7. Veronica persica Poir. & 0.9 & 3.0 & 2.5 & 3.3 \\
\hline 8. Neslia paniculata (L.) Desv. & 0.8 & - & - & - \\
\hline 9. Cerastium holosteoides Fr. Emend. Hyl. & 0.7 & - & 0.1 & 0.1 \\
\hline 10. Lamium amplexicaule $\mathrm{L}$. & 0.6 & 0.6 & 1.1 & 1.4 \\
\hline 11. Capsella bursa-pastoris (L.) Medik. & 0.4 & - & - & - \\
\hline 12. Veronica arvensis $\mathrm{L}$. & 0.2 & 2.0 & 1.2 & 1.3 \\
\hline 13. Fumaria officinalis L. & 0.1 & 0.1 & 0.2 & 0.1 \\
\hline 14. Myosotis arvensis (L.) Hill & 0.1 & & & 0.1 \\
\hline 15. Cirsium arvense (L.) Scop. & 0.0 & 0.0 & 0.0 & 0.3 \\
\hline 16. Galinsoga parviflora Cav. & 0.1 & - & - & - \\
\hline 17. Sinapis arvensis L. & 0.1 & - & - & - \\
\hline 18. Tussilago farfara $\mathrm{L}$. & 0.1 & - & - & - \\
\hline 19. Geranium pusillum Burm. f. ex L. & 0.0 & 0.2 & & \\
\hline 20. Convolvulus arvensis L. & - & 0.0 & 0.1 & 0.2 \\
\hline 21. Fallopia convolvulus (L.) Á. Löve & - & 0.0 & - & - \\
\hline 22. Sonchus arvensis L. & - & & 0.3 & 0.2 \\
\hline Total dicotyledonous & 115.3 & 43.3 & 43.9 & 58.9 \\
\hline Number of dicotyledonous species & 19 & 13 & 13 & 14 \\
\hline \multicolumn{5}{|l|}{ Monocotyledonous** } \\
\hline 23. Apera spica-venti (L.) P. Beauv. & 23.1 & 17.0 & 21.4 & 20.2 \\
\hline 24. Elymus repens (L.) Gould & 0.4 & 0.1 & 0.1 & 0.3 \\
\hline 25. Pоа аппиа L. & - & 0.1 & 0.1 & 0.1 \\
\hline 26. Equisetum arvense L. & - & 0.1 & - & 0.0 \\
\hline Total monocotyledonous & 23.5 & 17.3 & 21.6 & 20.6 \\
\hline Number of monocotyledonous species & 2 & 4 & 3 & 4 \\
\hline Total number of weeds & 138.8 & 60.6 & 65.5 & 79.5 \\
\hline Number of species & 21 & 17 & 16 & 18 \\
\hline
\end{tabular}

0.0 - Species occurring in less than 0.1 per $\mathrm{m}^{2}$

- Species not occurring

* Explanation as in Table 1

** With Equisetum arvense L. 
Table 4

Species composition and number of weeds per $1 \mathrm{~m}^{2}$ of a winter wheat canopy before harvest in dependent on doses of herbicides (means from the years 2006-2008).

\begin{tabular}{|c|c|c|c|c|}
\hline \multirow{2}{*}{ Species } & \multicolumn{4}{|c|}{ Doses of herbicides } \\
\hline & $* \mathrm{~A}$ & $\mathrm{~B}$ & $\mathrm{C}$ & $\mathrm{D}$ \\
\hline \multicolumn{5}{|l|}{ Dicotyledonous } \\
\hline 1. Galium aparine $\mathrm{L}$. & 15.5 & 2.9 & 4.2 & 4.6 \\
\hline 2. Viola arvensis Murray & 7.6 & 10.0 & 8.5 & 10.3 \\
\hline 3. Papaver rhoeas $\mathrm{L}$. & 3.2 & 0.7 & 0.7 & 0.5 \\
\hline 4. Matricaria maritima subsp. inodora (L.) Dostál & 2.0 & 0.5 & 0.5 & 0.8 \\
\hline 5. Fallopia convolvulus (L.) Á. Löve & 1.1 & 1.3 & 1.0 & 1.3 \\
\hline 6. Convolvulus arvensis $\mathrm{L}$. & 0.6 & 1.1 & 1.0 & 0.2 \\
\hline 7. Stellaria media (L.) Vill. & 0.6 & 0.9 & - & 0.2 \\
\hline 8. Consolida regalis Gray & 0.3 & 0.3 & 0.1 & 0.1 \\
\hline 9. Melandrium album (Mill.) Garcke & 0.2 & - & 0.2 & 0.2 \\
\hline 10. Sonchus arvensis L. & 0.1 & 0.1 & 0.2 & 0.3 \\
\hline 11. Cirsium arvense (L.) Scop. & - & 0.2 & 0.2 & 0.3 \\
\hline 12. Veronica arvensis L. & - & 0.1 & 0.3 & - \\
\hline 13. Myosotis arvensis (L.) Hill & - & 0.1 & 0.1 & 0.1 \\
\hline 14. Conyza canadensis (L.) Cronquist & - & 0.1 & - & - \\
\hline 15. Chenopodium album $\mathrm{L}$. & - & 0.1 & - & - \\
\hline 16. Anagallis arvensis L. & - & - & 0.2 & - \\
\hline 17. Artemisia vulgaris L. & - & - & 0.1 & - \\
\hline Total dicotyledonous & 31.2 & 18.4 & 17.3 & 18.9 \\
\hline Number of dicotyledonous species & 10 & 14 & 14 & 12 \\
\hline \multicolumn{5}{|l|}{ Monocotyledonous** } \\
\hline 18. Apera spica-venti (L.) P. Beauv. & 21.4 & 13.2 & 19.7 & 19.1 \\
\hline 19. Elymus repens (L.) Gould & 1.9 & 1.0 & 1.0 & 0.9 \\
\hline 20. Avena fatua $\mathrm{L}$. & 0.6 & 0.7 & 0.9 & 0.7 \\
\hline 21. Setaria pumila (Poir.) Roem. \& Schult. & 0.1 & 1.8 & 1.1 & 0.3 \\
\hline 22. Equisetum arvense L. & - & 0.2 & 0.2 & 0.2 \\
\hline Total monocotyledonous & 24.0 & 16.9 & 22.9 & 21.2 \\
\hline Number of monocotyledonous species & 4 & 5 & 5 & 5 \\
\hline Total number of weeds & 55.2 & 35.3 & 40.2 & 40.1 \\
\hline Number of species & 14 & 19 & 19 & 17 \\
\hline
\end{tabular}

0.0 - Species occurring in less than 0.1 per $\mathrm{m}^{2}$

- Species not occurring

* Explanation as in Table 1

** With Equisetum arvense L. 
Table 5

Species composition and number of weeds per $1 \mathrm{~m}^{2}$ of a winter wheat canopy at the first date of weed infestation estimation (BBCH development stage 41-45) in dependent on foliar fertilization application (means from the years 2006-2008).

\begin{tabular}{|c|c|c|c|}
\hline \multirow[b]{2}{*}{ Dicotyledonous } & \multicolumn{3}{|c|}{ Foliar fertilizers } \\
\hline & Control & Insol 3 & FoliCare \\
\hline 1. Galium aparine $\mathrm{L}$. & 34.0 & 25.4 & 30.1 \\
\hline 2. Viola arvensis Murray & 15.8 & 17.8 & 16.4 \\
\hline 3. Papaver rhoeas $\mathrm{L}$. & 9.4 & 11.6 & 8.5 \\
\hline 4. Veronica persica Poir. & 2.5 & 1.6 & 3.2 \\
\hline 5. Lamium amplexicaule $\mathrm{L}$. & 1.1 & 0.3 & 1.3 \\
\hline 6. Stellaria media (L.) Vill. & 1.3 & 0.5 & 1.5 \\
\hline 7. Veronica arvensis $\mathrm{L}$. & 0.8 & 1.8 & 0.9 \\
\hline 8. Matricaria maritima subsp. inodora (L.) Dostál & 0.8 & 0.8 & 0.7 \\
\hline 9. Cerastium holosteoides Fr. Emend. Hyl. & 0.3 & 0.2 & 0.2 \\
\hline 10. Capsella bursa-pastoris (L.) Medik. & 0.3 & - & 0.1 \\
\hline 11. Neslia paniculata (L.) Desv. & 0.2 & 0.2 & 0.2 \\
\hline 12. Fumaria officinalis L. & 0.1 & 0.1 & 0.1 \\
\hline 13. Convolvulus arvensis $\mathrm{L}$. & 0.1 & 0.1 & 0.0 \\
\hline 14. Myosotis arvensis (L.) Hill & 0.1 & 0.1 & 0.0 \\
\hline 15. Galinsoga parviflora Cav. & 0.1 & - & - \\
\hline 16. Tussilago farfara $\mathrm{L}$. & 0.1 & - & - \\
\hline 17. Cirsium arvense (L.) Scop. & 0.0 & 0.0 & 0.2 \\
\hline 18. Fallopia convolvulus (L.) Á. Löve & 0.0 & & - \\
\hline 19. Camelina sativa (L.) Crantz & - & 4.6 & - \\
\hline 20. Geranium pusillum Burm. f. ex L. & - & 0.1 & - \\
\hline 21. Sonchus arvensis L. & - & 0.2 & 0.1 \\
\hline 22. Sinapis arvensis L. & - & - & 0.1 \\
\hline Total dicotyledonous & 66.9 & 65.4 & 63.6 \\
\hline Number of dicotyledonous species & 18 & 17 & 17 \\
\hline \multicolumn{4}{|l|}{ Monocotyledonous* } \\
\hline 23. Apera spica-venti (L.) P. Beauv. & 16.6 & 22.9 & 21.7 \\
\hline 24. Elymus repens (L.) Gould. & 0.1 & 0.0 & 0.6 \\
\hline 25. Роа аппиа $\mathrm{L}$. & 0.1 & 0.1 & 0.1 \\
\hline 26. Equisetum arvense L. & 0.0 & 0.1 & 0.0 \\
\hline Total monocotyledonous & 16.8 & 23.1 & 22.4 \\
\hline Number of monocotyledonous species & 4 & 4 & 4 \\
\hline Total number of weeds & 83.7 & 88.5 & 86.0 \\
\hline Number of species & 22 & 21 & 21 \\
\hline
\end{tabular}

0.0 - Species occurring in less than 0.1 per $\mathrm{m}^{2}$

- Species not occurring

* With Equisetum arvense L. 
Table 6

Species composition and number of weeds per $1 \mathrm{~m}^{2}$ of a winter wheat canopy before harvest in dependent on foliar fertilization application (means from the years 2006-2008).

\begin{tabular}{|c|c|c|c|}
\hline \multirow[b]{2}{*}{ Dicotyledonous } & \multicolumn{3}{|c|}{ Foliar fertilizers } \\
\hline & Control & Insol 3 & FoliCare \\
\hline 1. Viola arvensis Murray & 8.6 & 8.5 & 10.2 \\
\hline 2. Galium aparine $\mathrm{L}$. & 6.9 & 6.4 & 7.3 \\
\hline 3. Fallopia convolvulus (L.) Á. Löve & 1.3 & 0.8 & 1.4 \\
\hline 4. Papaver rhoeas $\mathrm{L}$. & 1.2 & 1.2 & 1.4 \\
\hline 5. Matricaria maritima subsp. inodora (L.) Dostál & 0.8 & 0.9 & 1.1 \\
\hline 6. Stellaria media (L.) Vill. & 0.6 & 0.2 & 0.4 \\
\hline 7. Convolvulus arvensis $\mathrm{L}$. & 0.5 & 1.2 & 0.6 \\
\hline 8. Consolida regalis Gray & 0.2 & 0.2 & 0.1 \\
\hline 9. Cirsium arvense (L.) Scop. & 0.1 & 0.2 & 0.2 \\
\hline 10. Melandrium album (Mill.) Garcke & 0.1 & 0.2 & 0.1 \\
\hline 11. Sonchus arvensis L. & 0.1 & 0.1 & 0.3 \\
\hline 12. Chenopodium album L. & 0.1 & - & - \\
\hline 13. Myosotis arvensis (L.) Hill & 0.1 & 0.1 & 0.1 \\
\hline 14. Conyza canadensis (L.) Cronquist & 0.1 & - & - \\
\hline 15. Veronica arvensis L. & - & 0.2 & 0.1 \\
\hline 16. Anagallis arvensis $\mathrm{L}$. & - & 0.1 & 0.0 \\
\hline 17. Artemisia vulgaris $\mathrm{L}$. & - & - & 0.1 \\
\hline Total dicotyledonous & 20.7 & 20.3 & 23.4 \\
\hline Number of dicotyledonous species & 14 & 14 & 15 \\
\hline \multicolumn{4}{|l|}{ Monocotyledonous } \\
\hline 18. Apera spica-venti (L.) P. Beauv. & 14.0 & 17.2 & 24.3 \\
\hline 19. Elymus repens (L.) P. Beauv. & 1.2 & 1.2 & 1.2 \\
\hline 20. Setaria pumila (Poir.) Roem. \& Schult. & 0.8 & 0.9 & 0.7 \\
\hline 21. Avena fatua $\mathrm{L}$. & 0.6 & 1.0 & 0.4 \\
\hline 22. Equisetum arvense $\mathrm{L}$. & - & 0.3 & - \\
\hline Total monocotyledonous & 16.6 & 20.6 & 26.6 \\
\hline Number of monocotyledonous species & 4 & 5 & 4 \\
\hline Total number of weeds & 37.3 & 40.9 & 50.0 \\
\hline Number of species & 18 & 19 & 19 \\
\hline
\end{tabular}

0.0 - Species occurring in less than 0.1 per $\mathrm{m}^{2}$

- Species not occurring

* With Equisetum arvense L. 
Table 7

Characteristics of RAPD primers selected to estimate polymorphism of Galium aparine populations.

\begin{tabular}{|c|c|c|c|c|}
\hline \multirow{2}{*}{ Primer } & \multirow{2}{*}{$\begin{array}{l}\text { Primer sequence } \\
\text { 5'-3' }\end{array}$} & \multicolumn{2}{|c|}{ Number of bands } & \multirow{2}{*}{$\begin{array}{l}\text { Range of molecular weight } \\
\text { (bp) }\end{array}$} \\
\hline & & total & polymorphic & \\
\hline A-05 & AGG GGT CTT G & 8 & 8 & $2500-500 \mathrm{bp}$ \\
\hline A-07 & GAA AAG GGT G & 9 & 7 & $1500-300 \mathrm{bp}$ \\
\hline A-11 & CAA TCG CCG T & 10 & 9 & $2000-600 \mathrm{bp}$ \\
\hline F-05 & CCG AAT TCC C & 5 & 5 & $1300-350 \mathrm{bp}$ \\
\hline H-17 & САC ТСТ ССТ C & 8 & 8 & $1600-400 \mathrm{bp}$ \\
\hline $\mathrm{J}-05$ & CTC CAT GGG G & 7 & 7 & $1500-430 \mathrm{bp}$ \\
\hline L-02 & TGG GCG TCA A & 5 & 4 & $1500-250 \mathrm{bp}$ \\
\hline M-07 & CCG TGA CTC A & 7 & 7 & $1200-300 \mathrm{bp}$ \\
\hline P-06 & GTG GGC TGA C & 4 & 4 & $1000-550 \mathrm{bp}$ \\
\hline $\mathrm{T}-01$ & CGC AGT ACT C & 9 & 7 & $1200-400$ bp \\
\hline Total & & 72 & 66 & - \\
\hline Average $\mathrm{p}$ & mer & 7.2 & 6.6 & - \\
\hline
\end{tabular}

Table 8

Characteristics of RAPD primers selected to estimate polymorphism of Apera spica-venti populations.

\begin{tabular}{|c|c|c|c|c|}
\hline \multirow{2}{*}{ Primer } & \multirow{2}{*}{ Primer sequence $5{ }^{\prime}-3$ ' } & \multicolumn{2}{|c|}{ Number of bands } & \multirow{2}{*}{$\begin{array}{c}\text { Range of molecular } \\
\text { weight }\end{array}$} \\
\hline & & total & polymorphic & \\
\hline A09 & GGG TAA CGC C & 10 & 9 & $1500-320$ bp \\
\hline A12 & TCG GCG ATA G & 10 & 9 & $1600-350 \mathrm{bp}$ \\
\hline A14 & TCT GTG CTG G & 9 & 9 & $2000-600 \mathrm{bp}$ \\
\hline M07 & CCG TGA CTC A & 9 & 8 & $1300-350 \mathrm{bp}$ \\
\hline U136 & TAC GTC TTG C & 11 & 10 & $1600-400 \mathrm{bp}$ \\
\hline U386 & TGT AAG CTC G & 7 & 5 & $1500-430 \mathrm{bp}$ \\
\hline X06 & TCC GAG TCT G & 10 & 10 & $1500-400 \mathrm{bp}$ \\
\hline Total & & 66 & 60 & - \\
\hline Average per primer & & 9.4 & 8.6 & - \\
\hline
\end{tabular}




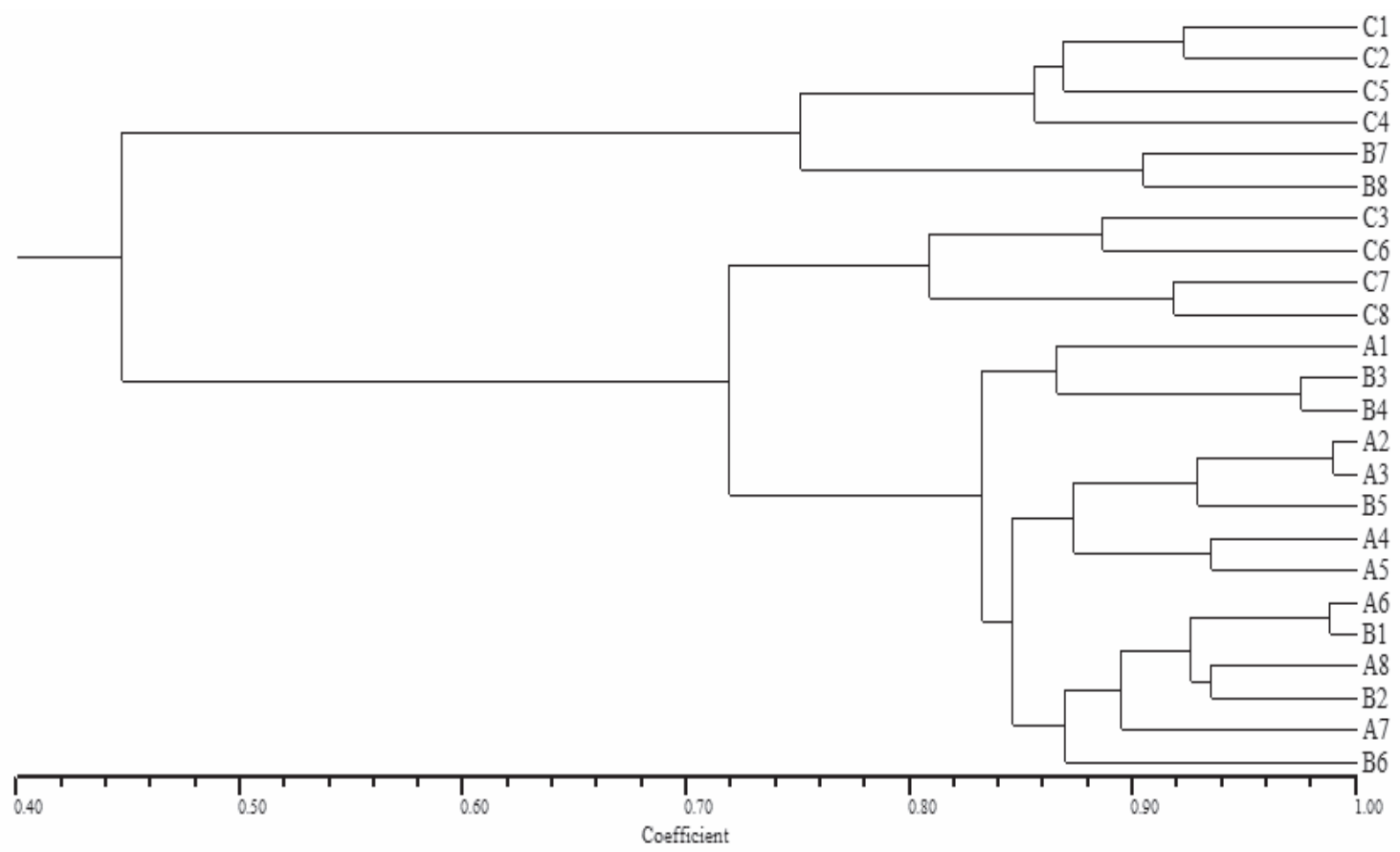

Fig. 1. UPGMA dendrogram of Galium aparine forms based on RAPD markers.

A - population from the plot where doses of herbicides were reduced to $50 \%$

$\mathrm{B}$ - population growing in the plot where herbicides were applied at full recommended doses $\mathrm{C}$ - control population

Numerals 1-8 mean the numbers of probes from the population

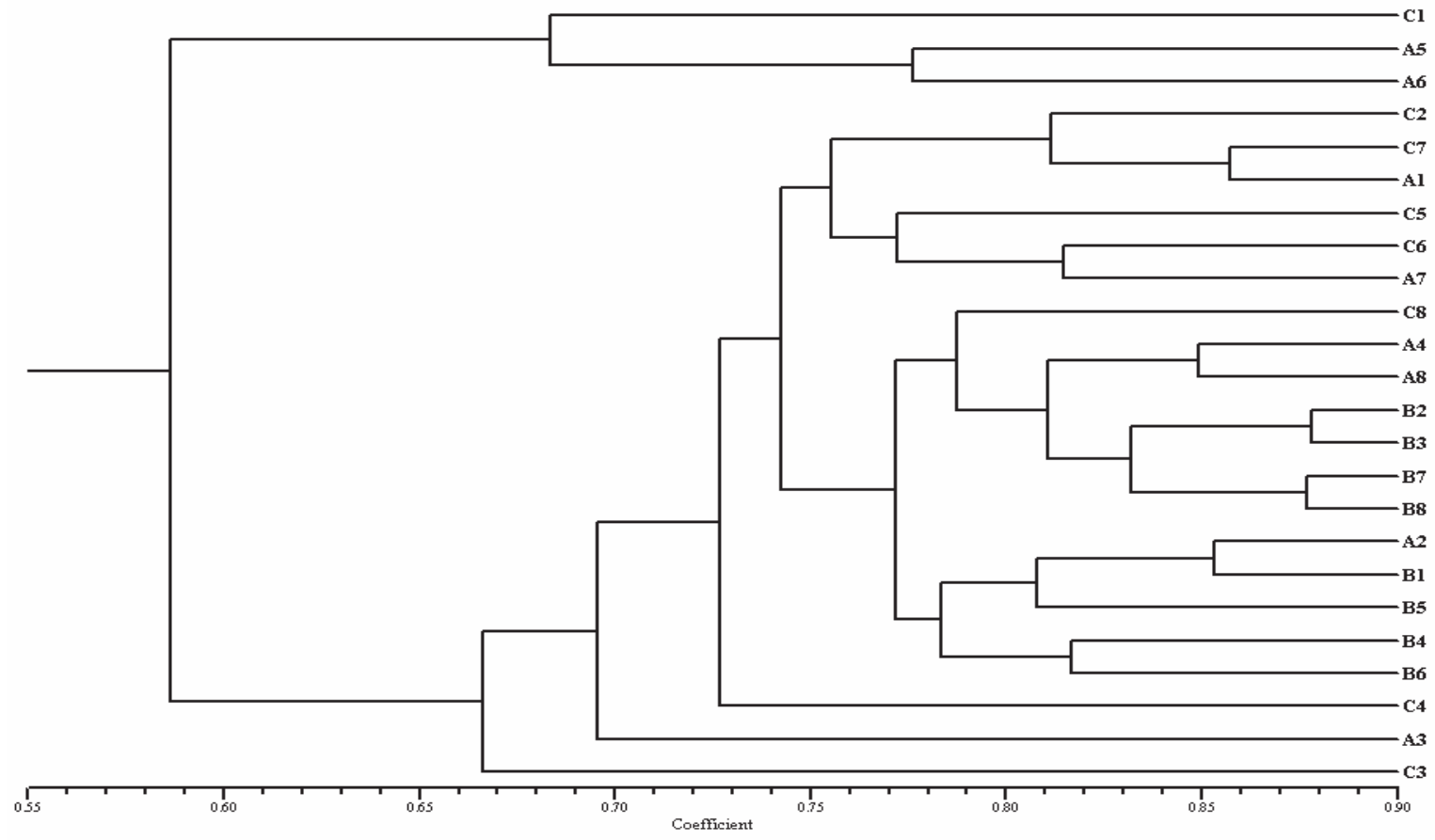

Fig. 2. UPGMA dendrogram of Apera spica-venti forms based on RAPD markers.

A - population from the plot where doses of herbicides were reduced to $50 \%$

$\mathrm{B}$ - population growing in the plot where herbicides were applied at full recommended doses

$\mathrm{C}$ - control population

Numerals 1-8 mean the numbers of probes from the population 
In the herbicide-treated plots, compared to the control treatments, a distinctly lower number of weed species was found on the first date of weed infestation estimation. At the same time, at this date the greatest species diversity was found in the variant with the half recommended herbicide dose in the treatments in which the herbicides were applied (Tab. 3).

At the first date of weed infestation estimation, the applied herbicides eliminated, compared to the control with no herbicides: Camelina sativa, Neslia paniculata, Capsella bursa-pastoris, Galinsoga parviflora, Sinapis arvensis, Tussilago farfara. At the same time, they significantly reduced the occurrence of Galium aparine and Papaver rhoeas, but only slightly Apera spica-venti (Tab. 3).

At the second date of weed infestation estimation, the largest number of species was found in the treatments with the full recommended herbicide dose and with the dose reduced down to $75 \%$ (19 in each). 17 species were found in the treatment with the herbicide rate reduced by half, whereas 14 taxa in the control treatment (Tab. 4). In the group of dicotyledonous species, Galium aparine, Papaver rhoeas and Viola arvensis were found in greatest numbers at both estimation dates, whereas Apera spica-venti from the group of monocotyledonous species (Tabs 1-4).

At the first date of weed infestation estimation, 17 dicotyledonous and 4 monocotyledonous species were found in the foliar fertilization treatments, but in the control treatment 22 species, including 18 dicotyledonous ones (Tab. 5). At the second date of weed infestation estimation, 19 species were found in the foliar fertilization treatments, whereas 18 taxa in the control (Tab. 6).

From among 30 primers tested, 10 primers generating stable and repeatable banding patterns were selected for analysis of the similarity index of Galium aparine. The primers amplified a total of 72 fragments, out of which 66 were polymorphic. The number of polymorphic fragments ranged from 4 to 9 for a single primer; on the average there were 6.6 amplicons per primer. The size range of polymorphic bands was from 250 bp to 2500 bp (Tab. 7).

The results of analysis of RAPD marker polymorphism formed the basis for the creation of the Dice similarity index matrix. The similarity index values ranged from 0.446 to 0.984 , with the average value being 0.860. Based on the SI matrix, the UPGMA analysis was performed (Fig. 1). 5 groups of clusters were observed on the dendrogram obtained. Genotypes from all the studied populations were grouped together in nearly each group. In the first group of clusters, genotypes from the control population and 2 genotypes from the plot in which the full herbicide dose was applied were clustered together. In the second group,
4 genotypes from the control population were clustered together, and in the third group of clusters, 3 genotypes were located: one from the population growing in the plot treated with the reduced herbicide dose and 2 genotypes from the population growing in the plot treated with the full herbicide dose. In the fourth group of clusters, 4 genotypes were located from the population treated with the reduced herbicide dose and one genotype from the population treated with the full herbicide dose. In the fifth group of clusters, there were 3 genotypes from the population growing in the plot treated with the reduced herbicide dose and 6 genotypes from the plot treated with the full herbicide dose.

7 primers generating stable and repeatable banding patterns were selected for analysis of the similarity index of Apera spica-venti. A total of 66 fragments were obtained, out of which 60 were polymorphic. The number of polymorphic fragments ranged from 5 to 10 for a single primer; on the average there were 9.4 amplicons per primer. The size range of polymorphic bands was from 320 bp to 2000 bp (Tab. 8).

The Dice similarity index values estimated for the Apera spica-venti population ranged from 0.586 to 0.878 , with the average value being 0.709 . Based on the SI matrix, the UPGMA analysis was performed (Fig. 2). Two groups of clusters can be distinguished on the dendrogram obtained. In the first group, 2 genotypes were located from the population growing the plot in which the herbicide dose reduced by $50 \%$ was applied and one genotype from the control population. 3 subgroups can be distinguished in the second group of clusters. In subgroup A, 4 genotypes from the control population and 2 genotypes from the population treated with the reduced herbicide dose were located. In subgroup B, 4 genotypes from the population growing in the plot treated with the full herbicide dose, 2 genotypes from the population growing in the plot in which the reduced herbicide dose was applied and one genotype from the control group were located. In subgroup C, 4 genotypes from the population treated with the full herbicide dose and one genotype from the population treated with the reduced herbicide dose were located. On the edges of the second group of clusters, there were 2 genotypes from the control group and one genotype from the population growing in the plot treated with the reduced herbicide dose.

\section{DISCUSSION}

At the first date of weed infestation estimation, the applied doses of the herbicides Mustang $306 \mathrm{SE}$ (florasulam and 2.4 D EHE) and Attribut 70 WG (propoxycarbazone sodium) reduced the number of weeds from $42.7 \%$ to $56.3 \%$, whereas their air-dry weight from $75.7 \%$ to $85.9 \%$. Before harvest, the number of weeds in the treatments in which the herbicides were 
applied was lower, compared to the control, from $27.2 \%$ to $36.1 \%$, whereas in the case of air-dry weight from $77.1 \%$ to $81.5 \%$. When applying in a winter wheat crop the herbicide Atlantis 04 WG (containing two active substances: mesosulfuron-methyl 30 $\mathrm{gxkg}^{-1}+$ iodosulfuron-methyl-sodium $6{\mathrm{~g} \times \mathrm{kg}^{-1} \text { and as }}$ a safener mefenpyr-diethyl $\left.90 \mathrm{~g} \times \mathrm{kg}^{-1}\right)$ and Factor 365 EC (containing $5 \mathrm{~g} \times \mathrm{l}^{-1}$ of metosulam and $360 \mathrm{~g} \times \mathrm{l}^{-1} 2.4$ D), Kras k a (2006) achieved a greater reduction in the number (from $67.0 \%$ to $80.5 \%$ ) and dry weight of weeds (from $81.4 \%$ to $92.5 \%$ ) at the first date of estimation, and at the second date, the number of weeds decreased from $81.8 \%$ to $86.3 \%$ and air-dry weight of weeds - from $81.8 \%$ to $90.6 \%$.

The effectiveness in the reduction of weed species occurring in greatest numbers in the wheat canopy, in particular Galium aparine and Apera spica-venti, decreased in the treatments with the reduced herbicide dose. K r a s k a $(2006,2007$ a) obtained similar correlations with regard to the same species on the same soil type. Wh it ing et al. (1991) found that it was possible to reduce the occurrence of dicotyledonous species and Apera spica-venti in cereals by the application of herbicides at reduced rates from 30 up to $60 \%$. On the other hand, D a vies and Whit ing (1989), when applying herbicides containing isoproturon, did not find any difference in the effectiveness of control of Apera spica-venti between the full dose and the dose reduced down to 50\%. Similarly, K r a s k a (2006) achieved high effectiveness of control of Apera spica-venti from $95.1 \%$ to $97.5 \%$ by applying mesosulfuron-methyl + iodosulfuron-methyl-sodium and metosulam $+2.4 \mathrm{D}$ at full doses and doses reduced by half. In the authors' study, the effectiveness of control of Apera spica-venti was much lower and it was, at the first date of weed infestation estimation, from $7.4 \%$ to $26.4 \%$, whereas at the second date from $7.9 \%$ to $38.3 \%$. High effectiveness in the control of Galium aparine (96-98\%) in spring cereals was achieved by Domaradzki (2006a) with respect to the mixture $2.4 \mathrm{D}+$ florasulam, but only when it was applied at a full rate and a rate reduced by $25 \%$. Slightly lower effectiveness in the reduction in the numbers of this species was achieved in the authors' study. At the first date of weed infestation estimation, it was from $64.8 \%$ to $79.1 \%$, whereas at the second date from $70.3 \%$ to $81.3 \%$.

The obtained results indicate the possibility of reducing herbicide doses in a winter wheat crop grown on rędzina without the risk of increased weed infestation. Davies and Whiting (1989), S pandl et al. (1997), Domaradzki (2006b) as well as K r a s k a (2006) also showed that it was possible to reduce herbicide doses from $20 \%$ to $50 \%$ without a significant reduction in winter and spring cereal yields, maintaining the required weed-killing effectiveness.
Herbicide application in a crop canopy limits its weed infestation, but at the same time it may decrease the number of species composing a weed community (A damiak and Z aw iślak, 1992; J ę d r u s z c z a k, 1998). As a consequence, it may lead to the development of communities with several species strongly competitive to a crop plant (R o la, 1991; Stupnicka-Rodzynkiewicz et al. 1988). It found confirmation in the present study, but only at the first date of weed infestation estimation, at which the number of species in the treatments where herbicides were applied was lower than in the control treatment. But before harvest, a completely reverse situation was found, notably, the control treatment proved to be the least floristically diverse. Probably, the applied herbicide doses, while limiting weed infestation with the dominant species, in particular, Galium aparine and Apera spica-venti, enabled, in the second part of the growing period, germination and growth of the species which were smothered by strong dominants in the control plot. K r a s a (2007a) found a similar situation in another study on the same soil type. Paw łowski and Wesołowski (1982) as well as R o la (1991) found that a single dominant species was more harmful for a crop plant than a multi-species community.

Foliar fertilization used in the present experiment did not have any effect on the weed infestation level in the winter wheat crop.

The RAPD method has been used many times to estimate genetic differentiation of many plant species (M a rtins - L o pe s et al. 2007; M a rtins a et al. 2006; K a n t et al. 2006). H ü bner et al. (2003) analysed cleavers populations from different countries and they found a low correlation between genetic differentiation of the studied populations and their geographic origin. Ern s t (2003) analysed genetic variation of cleavers populations based on RAPD markers. Out of 40 RAPD primers analysed, the author selected 17 primers generating polymorphic banding patterns. In the presented study, 10 RAPD primers generating repeatable and polymorphic banding patterns were selected for analysis of polymorphism of the studied Galium aparine populations, whereas 7 such primers were selected for analysis of Apera spica-venti. Similarly to the present study, the author found that the Galium aparine population in question was genetically diverse. In addition, the author did not find any correlation between the results of molecular analysis and herbicide sensitivity tests. Also in the authors' study, no correlation was found between the application of different herbicide doses and variation in genetic similarity of the studied populations of Galium aparine and Apera spica-venti. 


\section{CONCLUSIONS}

1. Weed infestation of the winter wheat canopy was not significantly differentiated by the application of the full and reduced, by $25 \%$ and $50 \%$, doses of the herbicides Mustang 306 SE and Attribut 70 WG. It indicates the possibility of reducing herbicide rates in a winter wheat crop without the risk of increased weed infestation.

2. 6 weeks after herbicide application (the first date of weed infestation estimation), the most diverse floristic composition was found in the control treatment. But when estimating weed infestation before harvest, the number of weed species found in the treatments in which herbicides were applied was by far larger than in no-herbicide treatments.

3. The species dominant in the winter wheat canopy were Galium aparine, Papaver rhoeas, Viola arvensis and Apera spica-venti.

4. At both date of weed infestation estimation, the applied herbicides limited to the greatest degree the occurrence of Galium aparine and Papaver rhoeas, whereas Apera spica-venti only slightly.

5. The application of foliar fertilization did not have a significant effect on the weed infestation level in the winter wheat canopy.

6. The Galium aparine and Apera spica-venti populations in question, herbicide-treated or untreated, were characterised by high genetic similarity. The herbicide doses applied did not affect genetic variation of the weed population in question.

\section{REFERENCES}

Ad a mczewski K., Praczyk T., 1999. Strategy of weed control in small grain cereals. Pamiętnik Puławski, 114: 7-13.

Adamiak E., Zawiślak K., 1992. Porównanie zachwaszczenia zbóż ozimych i jarych nie chronionych i traktowanych herbicydami. / Weed infestation of winter and spring cereals grown on herbicide treated and non - treated plots. Zesz. Nauk. AR w Krakowie, 33, 261: 173-185.

Badowski M., Domaradzki K., Filipiak K., Franek M., Gołębiowska H., Kieloch., Kucharski M., Rola H., Rola J., Sadowski J., Sekutowski T., Zawerbny T., 2001. Metodyka doświadczeń biologicznej oceny herbicydów, bioregulatorów i adiuwantów. Cz. 1 Doświadczenia polowe. / Experimental methodology of biological estimation of herbicides, bioregulators and adjuvants. Part 1. Field experiments. Wydawnictwo IUNG.

Blackshaw R. E., O'donovan J. T., Harker K. N., Clayton G. W., Stougaard R. N., 2006. Reduced herbicide doses in field crops: A review. Weed Biology and Management, 6: 10-17.
Davies D. H. K., Whiting A. J., 1989. Yield responses to herbicide use and weed levels in winter wheat and spring barley in Scottish trials and consequences for economic models. The BCPC Conference - Weeds, 3: 955-960.

D o m a radzki K., 2006a. Minimum effective doses for $\mathrm{Ga}$ lium aparine control in spring cereals. Prog. Plant Protection. / Post. Ochr. Roślin, 46 (2): 267-272.

D o m a r a z k i. K., 2006b. Effectiveness of the weed control in cereals in the aspect of reducing herbicide doses and selected agroecological factors. Monografie i Rozprawy Naukowe, Puławy, 17: 5-111.

Domaradzki K., Rola H., 1999. Regulation of cereals weed infestation level by herbicides used in lower rates. Pamiętnik Puławski, 114: 63-71.

Domaradzki K., Rola H., 2000. Efektywność stosowania niższych dawek herbicydów w zbożach. / The effectiveness of application of reduced herbicide rates in cereals. Pamiętnik Puławski, 120 (1): 53-64.

Domaradzki K., Rola H., 2004. Efficacy of reduced doses of amidosulfuron, fluroxypyr and tribenuronmethyl against Anthemis arvensis, Chenopodium album and Galium aparine. XII Colloque International Sur La Biologie Des Mauvaises Herbes. 31 aout-2 septembre 2004. Dijon-France, Annales AFPP: 543-648.

Doyle J. J., Doyle J. L., 1987. A rapid DNA isolation procedure for small quantities of fresh leaftissue. Phytochem. Bull. 19:11-15.

Ernst V., 2003. Zur Diversität von Galium aparine L.-Herkünften. Doctoral Diss. Hohenheim University.

Hübner R., Fykse H., Hurle K., Klemsdal S. S., 2003. Morphological differences, molecular characterization, and herbicide sensitivity of catchweed bedstraw (Galium aparine) populations. Weed Science, 51 (2): 214-225.

J ę d r u s z c z a k M., 1998. Niektóre ekologiczne skutki ochrony przed chwastami. / Some ecological effects of protection against weeds. Zagadnienia ochrony roślin w aspekcie rolnictwa integrowanego i ekologicznego. Mat. Konf. Szkoleniowej IUNG i IOR. Wyd. Puławy, 1998.

Kant A., Pattanayak D., Chakrabarti S. K., Sharma R., Thakur M., Sharma D. R., 2006. RAPD analysis of genetic variability in Pinus gerardiana Wall. in Kinnaur (Himachal Pradesh). Indian Biotechnology, 5: 62-67.

Kapeluszny J., Hal iniarz M., 2007. Expanding segetal weed species in central - east of Poland. Proceeding $14^{\text {th }}$ Symposium EWRS, Hamar-Norwey, Session, 7: 214.

K rask a P., 2006. The influence of different herbicides doses on winter wheat weed infestation. Prog. Plant Protection / Post. Ochr. Roślin, 46 (2): 256-260.

K rask a P., 2007a. Wpływ zróżnicowanych dawek herbicydów na zachwaszczenie pszenicy ozimej uprawianej w monokulturze. / The influence of different herbicide doses on winter wheat weed infestation cultivated in monoculture. Prog. Plant Protection / Post. Ochr. Roślin, 47 (3): 147-150. 
Kraska P., 2007b. Wpływ zróżnicowanych dawek herbicydów na plonowanie i zawartość makroelementów w ziarnie pszenicy ozimej. / The influence of different doses of herbicides on yielding and macroelements content in winter wheat grain. Biul. IHAR, 246: 23-30.

K raska P., 2008. The influence of different herbicide doses on weed infestation of winter triticale cultivated in monoculture. Acta Agrobot. 61 (2): 229-238.

K raska P., Pałys E., 2008. Plonowanie i skład chemiczny ziarna pszenżyta ozimego uprawianego w monokulturze w warunkach stosowania zróżnicowanych dawek herbicydów. / Grain yielding and chemical composition of winter triticale cultivated in monoculture in conditions of different doses herbicides. Ann. UMCS, 63 (2): 1-7.

Malicki L., Kwiecińska E., 1999. Fertility of common arable weed species on rendzina soil. Fragm. Agron. 3: 97-110.

Martins-Lopes P., Lima-Brito J., Gomes S., Meirinhos J., Santos L., Guedes-Pinto H., 2007. RAPD and ISSR molecular markers in Olea europaea L.: Genetic variability and molecular cultivar identification. Genet. Res. Crop Evol. 54: 117-128.

Martinsa S. R., Vencesb F. J., Sáenz de Mierab L. E., Barrosoc M. R., Carnidea V., 2006. RAPD analysis of genetic diversity among and within Portuguese landraces of common white bean (Phaseolus vulgaris L.). Scientia Horticulturae. 108: 133-142.

Ne i M., Li W. H., 1979. Mathematical model for studying genetic variatin in terms of restriction endonucleases. Proc. Natl. Acad. Sci. 76: 5269-5273.

Nowicki K., 1977. Występowanie, ekologia i chemiczne zwalczanie Galium aparine (L.) w pszenicy ozimej./ The occurrence, ecology and chemical control of $G a$ lium aparine (L.) in winter wheat. Wyd. IUNG R (123): $1-42$.

Pawłowski F., Wesołowski M., 1982. Liczebność i niektóre cechy biologiczne miotły zbożowej (Apera spica-venti L./PB.) w monokulturze pszenicy ozimej. / The numbers and some biological features of Apera (Apera spica-venti L./PB.) in winter wheat monoculture. Ann. UMCS, Sect. E, 37, 1: 1-8.

R ohlf F. J., 2001. NTSYS-pc numerical taxonomy and multivariate analysis system. Version 5.1.Exeter Publishing Ltd., Setauket, N.Y.

Rola J., 1991. Ekologiczno-ekonomiczne podstawy chemicznej walki z chwastami na polach uprawnych. / Ecological and economic backgrounds of chemical weed control. Mat. 31 Sesji Nauk IOR, 1: 110-124.

Rola H., 2002. Ecological and production aspects of plant protection against weeds. Pamiętnik Puławski, 2 (130): 635-645.

Spandl E., Durgan B. R., Miller D. W., 1997. Wild oat (Avena fatua) control in spring wheat (Triticum aestivum) and barley (Hordeum vulgare) with reduced rates of postemergence herbicides. Weed Technol. 11: 591-597.

Stupnicka-Rodzynkiewicz E., Łabza T., Hochó 1 T., 1988. Zmiany w zachwaszczeniu upraw zbożowych i okopowych w latach 1977-1985 na przykładzie wybranych kompleksów glebowych w makroregionie południowo-wschodnim. / Changes in weed infestation of cereal and root crops in the years 1977-1985 on chosen soil units in the south-eastern macroregion. Fragm. Agron. 3: 5-14.

Whiting A. J., Davies D. H. K., Brown H., Whytock G., 1991. The field use of reduced doses of broad-leaved weed herbicides in cereals. The BCPC Conference - Weeds, 3: 1209-1216.

Weide R. Y. van der., 1993. Population dynamics and population control of Galium aparine L., Chapter 1: $15-18$.

Williams J. G. K., Kubelik A. R., Livak K. J., Rafalski J. A., Tingey S.V., 1990. DNA polymorphisms amplified by arbitrary primers are useful as genetic markers. Nucl. Acid. Res. 18: 6531-6535.

\section{Zachwaszczenie łanu pszenicy ozimej w warunkach stosowania zróżnicowanych dawek herbicydów oraz nawożenia dolistnego}

\section{Streszczenie}

Badania przeprowadzono w latach 2006-2008 w Gospodarstwie Doświadczalnym Bezek niedaleko Chełma. W dwuczynnikowym doświadczeniu przeprowadzonym w układzie bloków losowanych porównywano działanie trzech dawek herbicydów oraz dwóch nawozów dolistnych w łanie pszenicy ozimej odmiany Turnia uprawianej w monokulturze. Herbicydy były stosowane w pełnych zalecanych dawkach, zredukowanych do $75 \%$ i do $50 \%$. Nawozy dolistne Insol 3 (N-11,5\%; Mg-2,84\%; B-0,28\%; Cu-0,56\%; Fe-1,20\%; Mn-1,68\%; Mo-0,01\%; Zn-1,12\%) i FoliCare $(\mathrm{N}-18,0 \%$; P-18,1\%; K-18,0\%; Mg-1,5\%; S-7,2\%; B- $0,02 \%$; Cu-0,10\%; Fe-0,20\%; Mn-0,10; Mo- $0,01 \%$; $\mathrm{Zn}-0,02 \%$ ) stosowano dwukrotnie w okresie wegetacji. Kontrolę stanowiły poletka na których nie stosowano zarówno herbicydów jak i nawozów dolistnych. W pracy oceniono poziom zachwaszczenia łanu (liczba osobników, skład gatunkowy i powietrznie sucha masa) pszenicy ozimej w 6 tygodni po zastosowaniu herbicydów Mustang $306 \mathrm{SE}$ (florasulam $-6,25 \mathrm{~g} \times \mathrm{l}^{-1}$; 2,4-D EHE - 300g $\times \mathrm{l}^{-1}$ ) i Attribut $70 \mathrm{WG}$ (70\% propoksykarbazonu sodowego) oraz przed zbiorem. Jednocześnie podjęto próbę sprawdzenia czy wielkość dawki herbicydu może wpływać na zmiany DNA gatunków dominujących w łanie pszenicy ozimej - Galium aparine i Apera spica-venti.

Poziom zachwaszczenia łanu pszenicy ozimej mierzony zarówno liczbą chwastów, jak i powietrznie suchą masą nie był istotnie różnicowany przez zastosowane dawki herbicydów. Uzyskane wyniki wskazują na możliwość obniżenia dawek herbicydów 
w łanie pszenicy ozimej bez ryzyka wzrostu poziomu zachwaszczenia. Nawożenie dolistne nie zmieniało poziomu zachwaszczenia łanu. Gatunkami dominującymi w łanie pszenicy ozimej w 6 tygodni po zastosowaniu herbicydów oraz przed zbiorem były Galium aparine, Papaver rhoeas oraz Viola arvensis, natomiast z jednoliściennych Apera spica-venti. Analiza molekularna nie wykazała, aby zastosowane dawki herbicydów wpłynęły na zróżnicowanie genetyczne Galium aparine i Apera spica-venti. 